\title{
Part 1 The Law
}

The first part of this book sets out the relevant law in respect of both the overarching European Court of Human Rights (ECtHR) and domestic legislation for England and Wales. It includes two chapters describing the overall human rights legal framework as well as the domestic law governing inquests following a death in custody. This part sets out the positive legal protections currently in place in relation to families participating in such inquests, as well as gaps where families cannot rely on the law to ensure participation.

Article 2(1) of the European Convention on Human Rights (ECHR) emphasises that a person's right to life shall be protected by law. In 1978, the ECtHR found that Article 2 of the ECHR not only prohibits the State from taking life but also places on it a positive duty to protect life. ${ }^{1}$ This protective aspect to the right to life has been re-affirmed and expanded upon through numerous decisions of the ECtHR: elucidating on when and what steps must be taken by a State to protect life. In 1995, the ECtHR found in McCann that in order to protect life, the State is required to ensure there is a proper investigation into any deaths caused by the use of force by State agents. ${ }^{2}$ Any investigation must be independent, prompt, contain a sufficient element of public scrutiny, and be capable of leading to a determination of whether State agents are liable'. ${ }^{3}$ The investigation must consider not just the actions of agents of the State but also the planning and organisation of the operation governing those actions. European case law has since clarified that situations where a death may have resulted due to a failure on behalf of the State to protect life should also be investigated; this includes deaths in State custody. The ECtHR has also laid out certain minimum requirements which are necessary for an investigation to be seen as compliant with Article 2; including the fact that there must be an opportunity for a bereaved family to participate in the process.

In domestic law, the inquest system is the process which investigates deaths in custody, unless criminal proceedings have fully looked into all relevant factors. Therefore an inquest is the legal process that ensures Article 2 requirements are met. The inquest system is an ancient system; the law which governs the system has evolved over hundreds of years, but in relation to deaths in custody, it is clear

\footnotetext{
${ }^{1}$ Association X v United Kingdom (1978) DR 14 (European Commission (Plenary)).

${ }^{2}$ McCann v United Kingdom (1996) 21 EHRR 97 (European Court of Human Rights).

${ }^{3}$ McCann v United Kingdom (1996) 21 EHRR 97 (European Court of Human Rights), para 201.
} 


\section{Death in Custody}

that domestic protections should meet ECtHR standards. It is therefore necessary to set out both ECtHR and domestic law, as well as highlight any diversions between the different jurisdictions that might illustrate potential challenges to ensuring compliance with Article 2 requirements.

Chapter 1 sets out how Article 2 has evolved from protecting life to requiring an investigation in certain situations where there is possible State involvement either in causing a death or failing to take adequate steps to protect life. Chapter 2 then looks at the specific domestic legal framework relating to the inquest system, especially for deaths that occur in custody. It also considers relevant legal requirements which relate to the purpose of an inquest, the role of bereaved families and specific rights that exist to allow their effective participation. But before that, the development of both European and domestic law in relation to Article 2 and the legal requirements around investigations into deaths in custody are discussed in the next chapter. 